
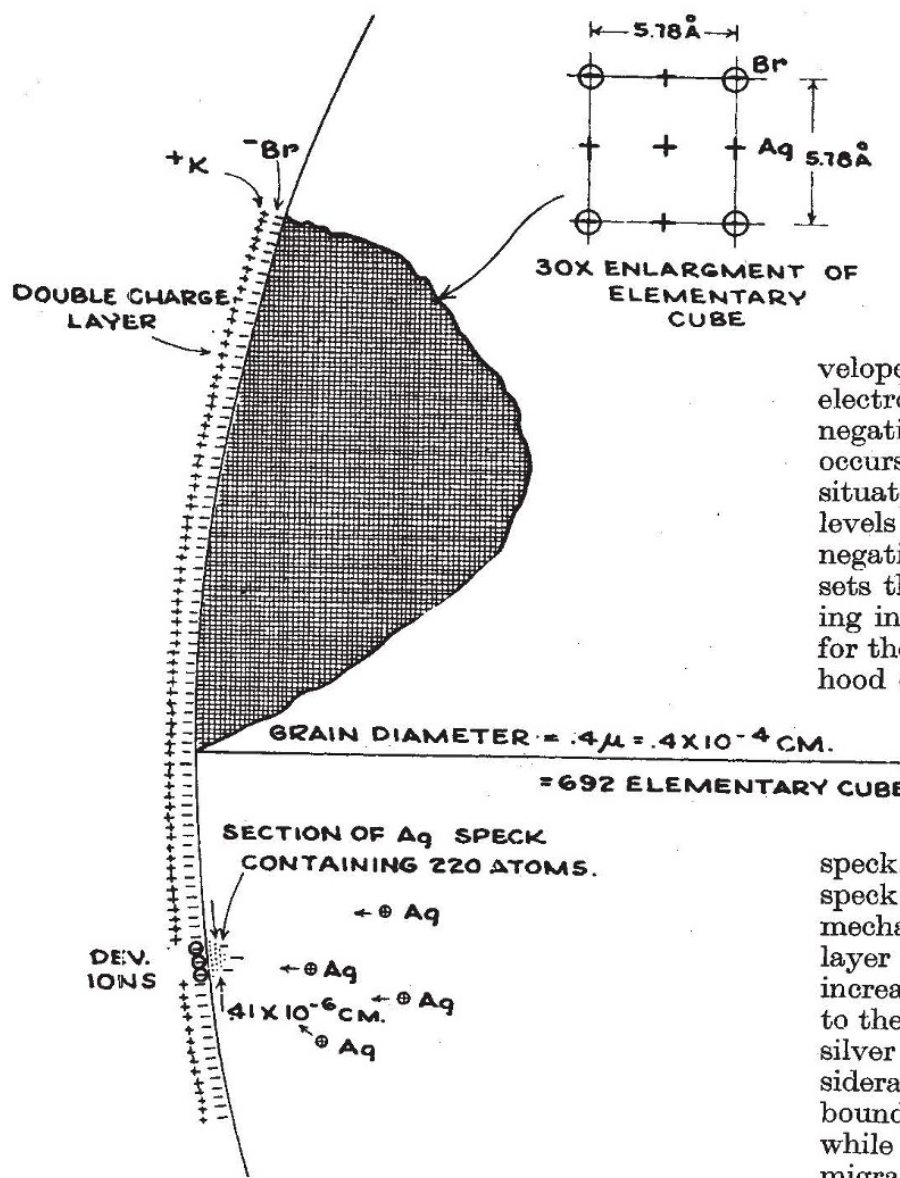

Fig. 5. Diagram SHOWING a LATENT IMAGE SPECK IN A SILVER BROMIDE CRYSTAL ATTACKED BY A DEVELOPER.

double-charge layer would be maintained. That the surface charges on the particles and surrounding charge layers do neutralize each other in the manner outlined is proved by the fact that the colloidal suspension does not possess a net charge of either sign but is neutral as a whole.

It may be assumed that a grain, owing to its double-charge layer, behaves toward outside charges and also those located inside the grain as a neutral body. An electron placed inside such a double-charge layer would experience no force nor, in the same way, would an electron placed outside such a double layer. However, there is a marked difference in potential between the inside and outside of the grain, and the total jump in this potential occurs in the region between the two charge layers. The potential gradient between these charge layers accordingly gives rise to a strong electrical force between the layers, and an electron placed between them would experience a force toward the outside. It is considered that the double-charge layer acts in this way as an effective potential barrier to the entrance of an electron into the silver bromide grain of the emulsion and prevents the developer from attacking the grain.

The conditions existing in the exposed grain con. taining a latent image silver speck may be seen in Fig. 5. This shows a greatly enlarged scale model of a charged grain surface with a clump of silver atoms on the surface, which is supposed to represent the latent image produced by exposure to light. The clump shown includes 220 atoms, with approximately the correct spacing. This size was chosen as representing a fair mean of the values given by various workers.

J. H. Webb assumes that development of a grain is initiated by the break in the doublecharge layer caused by the silver speck, permitting the negative developer ions to reach this silver speck. The latent image speck is viewed as an electrode penetrating into the grain. The tendency on the part of the developer ions to release electrons to the silver causes electrons to pass to the electrode and charge it negatively. As explained by Gurney and Mott, this occurs if the electrons of the developer ions are situated in levels above the highest occupied energy levels of the silver metal. The penetration of this negative electrode into the silver bromide grain upsets the neutral electrical condition previously existing in the grain, and there arises an attractive force for the positively charged silver ions in the neighbourhood of the latent-image speck.

Positive silver ions always exist in the crystal lattice owing to temperature motion, and these diffuse to the speck under the attraction of the negative charge there and enlarge the silver speck. Thus, it is supposed that the original silver speck of the latent image continues to grow by this mechanism. As this proceeds, the protective double layer is more and more ruptured, and a rapidly increasing area of the silver halide grain is exposed to the attack of the developer. Since the reduction of silver bromide by a developer is exothermic, considerable amounts of energy are liberated at the boundary between the silver and the silver bromide, while the local rise in temperature facilitates the migration of silver ions, so that the metallic silver is extruded as a filament.

The process of development itself involves certain requirements as to absorption and catalysis of the development reaction, which explain why one substance is a developer and another reducing agent having approximately the same reduction potential is not a developer. Much work remains to be done on the chemical reactions involved in development, but the knowledge which has recently become available as to the formation and nature of the latent image and its function in promoting the development of the silver halide grain has enabled us to form a much clearer picture of the phenomena of the photographic purocess than was possible previously.

\section{EFFICIENCY AND OUTPUT IN . AGRICULTURAL SYSTEMS*}

\author{
By Prof. A. W. ASHBY \\ University College of Wales, Aberystwyth
}

$T$ $\mathrm{HE}$ measurement of outputs of agricultural systems and their valuation are always a complex proceeding, and the results of any methods of measurement and valuation which have been used up to the present time are to some extent indefinite. Outputs vary in their physical and biochemical characteristics, and in their human uses and values. The only common measure of outputs of varied characters is their

* Excerpts from a paper read before the Royal Society of Arts on November 11 . 
money value at any given time. Relative prices of one product and another vary from time to time, and therefore the values of outputs of given quantities of products also vary. A system or type of farming which may be shown to be efficient at one period may prove to be relatively inefficient a short time later, due solely to changes which have occurred in markets.

In any economic and social system which is subject to major changes, adaptability to changes in markets for produce, in industrial production or commercial offers of the raw materials used and usable in agriculture, in industrial production of agricultural equipment, in supply and costs of human labour, must always be a test of farming efficiency. It may, indeed, be the acid test from which there is no hope of anything except a very temporary escape. There is scarcely any major change in the economic and social institutions and conditions of a nation which does not, sooner or later, affect forms of organization for agricultural production and their results.

A quarter of a century ago many essays were made to judge agricultural systems on their outputs of food values - in carbohydrates, fats, and proteins-in the common measure of calories. But modern knowledge of nutrition, by adding vitamins and minerals to the elements expected in food supplies, has severely qualified these tests. There is no common measure which can be applied to all the food values of the products of any two or more agricultural systems.

But even when we thought we were able to measure and value agricultural outputs in physical and biochemical terms, we were quite unable to measure inputs in these terms, and therefore were unable to judge the efficiencies of systems of production. The 'calorie' test was usually only quoted per acre of land, which itself is more a measure of superficial area than of productive eapacity, and any other test was rare. A simple illustration of this test shows its weakness.

The order of yields of calories and of protein per acre, of the following crops, in human use of the main products and of the secondary products of their by-products is :

$\begin{array}{llccc} & & & \begin{array}{c}\text { Calories } \\ \text { per acre } \\ \text { (order) }\end{array} & \begin{array}{c}\text { Protein } \\ \text { per acre } \\ \text { (order) }\end{array} \\ \text { Sugar Beet } & \ldots & \ldots . . & 1 & 3 \\ \text { Potatoes } & \ldots . & \ldots . & 2 & 1 \\ \text { Wheat } & \ldots . . & \ldots . & 3 & 2\end{array}$

While wheat and pig-meat produced by the offals give less than 45 per cent of the yield of calories obtained from sugar in sugar-beet and milk from tops, they give nearly three times the protein yield. But when the test of production per man-hour of labour is applied the order is entirely changed :

$\begin{array}{llccc} & & & \begin{array}{c}\text { Calories } \\ \text { per } \\ \text { man-hour }\end{array} & \begin{array}{c}\text { Protein } \\ \text { per } \\ \text { man-hour }\end{array} \\ \text { Sugar Beet } & \ldots . & \ldots . & 3 & 3 \\ \text { Potatoes } & \ldots . & \ldots . & 2 & 2 \\ \text { Wheat } & \ldots . & \ldots . & 1 & 1\end{array}$

Wheat gives much the largest return of energy per anit of manual labour--nearly three times the return of protein when compared with potatoes, and about eight times the return of protein when compared with sugar-beet.

We may, indeed we must, occasionally apply the physical and biochemical measures to agricultural outputs in relation to human food requirements or supplies. But they are only crude tests of efficiency in feeding the nation. They are not tests of efficiency in production.
Every nation at any time, and particularly in war-time, must seek to make the optimum use of each and all its resources; and the maximum use of land, maximum production per acre, tends to waste human energy everywhere. It nearly always wastes sweat, and not uncommonly blood and tears. A nation which has a very dense population, or a dense population tending to increase, and few resources other than its surface soil, may have no option but to seek maximum use of land, and highest possible production, but such a nation is to be pitied rather than envied. Or, in these days of close international relationships, we should say : pitied and assisted to find other outlets or uses for labour.

The general principle is that each nation will determine its standard of production per acre of land in relation to two main conditions : (1) the existence of other resources or means of useful employment of population ; (2) the standard of remuneration and of living established for workers in industries other than agriculture. When full examination is made of the economic and social conditions of nations with high density of agricultural population and high production per acre, it will be found that they adopt these conditions of necessity rather than choice. If they had other resources on which to use labour, they would modify their agricultural systems.

Efficiency, whether of motor-cars, of cows, or of crop-acres, is always measured by the ratio of output to inputs. Outputs are the results of inputs, with some factors, such as weather, which may be beyond the producer's control or even influence. Inputs are determined by the technical knowledge and the capital resources of the farmer and according to his judgment of the money costs and the money values of the expected result in outputs. Every single input may be applied with different degrees of economy and efficiency.

The main inputs are land, human labour-manual and managerial-and capital. But capital takes many concrete forms-in live and dead farming stock and materials. If we wish to apply even simple tests of efficiency of farming systems we must test production $(a)$ per unit of land, $(b)$ per unit of labour, $(c)$ per unit of capital. We must also test by the best combination of measures of these inputs that we can find. For this purpose each has to be valued and measured in money.

The productive capacity of land or farms in Great Britain is far better measured by money values as rentals than by superficial area. The productive capacity of two acres in different districts may vary as much as $100: 1$ and commonly varies as much as $25: 1$. Rental values tend to represent and to equalize measures of productive capacity. There is no other common measure of all the geophysical conditions which influence the productive capacities of different units of land as such.

The technical conditions of choice and application of some of the embodiments of capital, both fixed and circulating, are too varied for general discussion. But some conditions may be indicated. 'The efficiency of power sources and of implements and machinery has been rising. It appears that the input of feed required to produce a gallon of milk has fallen by about one sixth in this century because of selection of breeds, strains, and individual animals, and greater knowledge and better practices in feeding. The feed required to produce a given weight of mutton or lamb, and the time and probably the feed required to produce a 10-cwt. fat bullock, have also been reduced. 
The amount of feed required to produce a dozen eggs has been reduced by some 12-15 per cent. There is also evidence of rising efficiency in crop production.

The best simple measure of the general rise of efficiency is found in the output per man, which has probably risen about 70 per cent in the last seventy years. From 1925 to 1939 the increase was very rapid. Different criteria of efficiency may be applied by interested parties. If agriculturists as a community have to apply any single standard to production they will judge it by the net output per man (gross output less cost of raw materials and depreciation of equipment), for it is this which determines the possibilities of their standards of remuneration and of living. Having set a high standard of output per man, each elass can bargain for its distribution with the assistance of any social forces they can draw to their aid. But with a low standard of output the standard of remuneration of one or more of the classes, and possibly all, must be low.

The general practice seems to have been to make international comparisons mainly in terms of yields or outputs per acre. But recently there has been a change, and other tests have been applied. On the information now available, it appears that Great Britain will take different positions in an international order of productivity according to the test applied. In a list of twelve countries-New Zealand, Australia, Great Britain, U.S.A., Denmark, Canada, The Netherlands, Belgium, Switzerland, France, Germany, Eire -the position of Great Britain is : (1) value of output per acre, seventh; (2) persons fed per acre (on cash value basis), sixth; (3) persons fed per worker, third (excelled only by Australia and New Zealand); (4) value of output per worker, third (again excelled only by New Zealand and Australia). In a test with seven European countries-Great Britain, Germany, France, Denmark, Belgium, The Netherlands, and Switzerland-the position of Great Britain is : (1) value of gross and net output per acre, seventh; (2) value of output per worker, first ; (3) average income per whole-time person engaged, almost certainly first.

But in case there is a tendency still to judge yields or outputs per unit of superficial area of land, that is, per acre, it may be pointed out that among the seven European countries, Great Britain is second only to Denmark in gross output per pound sterling annual (rental) values, and second only to France on net output per pound sterling annual (rental) values when a standard rate of interest is applied to capital values of land in each country. The rate of interest on capital values represented by gross rents or prevailing rates of interest on mortgages is higher in Great Britain than in any of the European countries listed. Measuring gross and net outputs against annual values of land as determined by the prevailing interest rate in each country, which varies between about $\mathbf{2 \cdot 2}$ per cent in Belgium and about 5 per cent in Great Britain, this country stands fourth in the list.

If Great Britain wishes to retain an agricultural population, which will be satisfied and satisfactory from either economic or social points of view, it will continue to be necessary to maintain a high standard of net output per worker, and all other standards have to be fitted to this condition. Even in war-time we have to make the optimum use of labour ; we cannot afford to waste labour on unproductive land; we must use our labour where it will be most productive of the supplies of which the nation has the greatest need.
The nation will judge by the quantities and qualities of products offered for human use and consumption in relation to its requirements, normally expressed through the markets, but in war-time expressed through the administrative organs of the State (Ministries of Agriculture, Food and Supply). Beyond this the nation has never had any clear criteria. The interested but poorly informed public has many and often conflicting criteria. It wants reasonably cheap food, maximum employment of labour, maximum production from the land, more small holdings, higher if not maximum wages and better housing for farm workers. It wants more wheat for national defence, more milk and vegetables for health, more eggs and more and higher quality meats to stimulate appetites and to meet needs due to changes in industrial work, urban living, and standards of real incomes.

Specific tests are applicable for special purposes in certain circumstances. The agricultural system of each country is more or less fitted to its general economic and social conditions. The conditions established in one country are not necessarily to be sought by any other, and the standards applied in one country are not likely to have any real validity in any other, unless the general economic and social conditions are similar in both.

Perhaps the most acute controversy about standards of production and efficiency in the future will turn on the efficiency of large farms. Past studies of the smaller and larger farms in Great Britain have usually shown that the smaller farms had the higher outputs per acre and the lower outputs per man. But in any discussion of this problem it must be remem. bered that few of the large agricultural enterprises in the country have been organized on unitary holdings, and also that there is no public information on the details of organization, inputs and outputs of the best of the large enterprises in Great Britain. Before any firm judgment can be made on the relative economic and social results of the largest, the medium and the small enterprises, we need much more information on the largest enterprises. At present information is practically limited to the small and mediumsized businesses.

A further caveat must also be entered. Even if it were proved that the results of the larger enterprises now in existence are not any better than those of the medium-sized or other groups, that would not prove that large unitary enterprises could not be designed, organized and operated to yield highly satisfactory results.

\section{GEOLOGICAL MAKING OF INDIA}

$M^{R}$

R. D. N. WADIA, author of the well-known "Geology of India for Students", retired from the Geological Survey of India in 1938, and shortly after took up the appointment of mineralogist to the Government of Ceylon. $\mathrm{He}$ was president of the Geological Section of the Indian Science Congress at its jubilee session in Calcutta in 1938, and became general president of the whole Congress at the twenty-ninth session held this last January at Baroda; he is the third geologist to fill this position. During his Indian service Mr. Wadia was engaged mainly in the study and mapping of the postArchæan folded formations of north-western India, 